\title{
Site U1355
}

\author{
Expedition 318 Scientists $^{2}$
}

\section{Chapter contents}

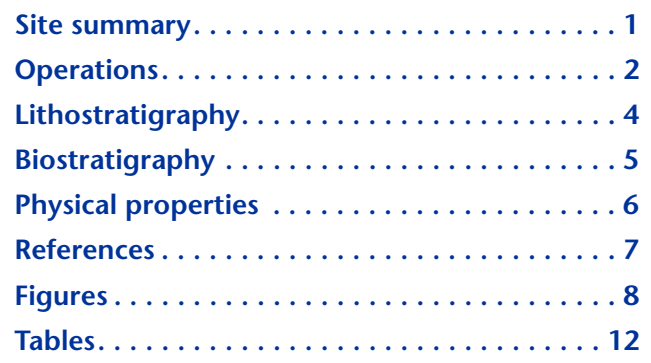

${ }^{1}$ Expedition 318 Scientists, 2011. Site U1355. In Escutia, C., Brinkhuis, H., Klaus, A., and the Expedition 318 Scientists, Proc. IODP, 318: Tokyo (Integrated Ocean Drilling Program Management International, Inc.).

doi:10.2204/iodp.proc.318.103.2011

'Expedition 318 Scientists' addresses.

\section{Site summary}

The primary objective at Integrated Ocean Drilling Program (IODP) Expedition 318 Site U1355 (proposed Site WLRIS-06A) was to core across unconformity WL-U3 to obtain the timing and nature of the first arrival of the ice sheet to the Wilkes Land Continental Margin in a distal setting. Site U1355 is at the transition between the continental rise and the abyssal plain in a water depth of 3723 meters below sea level (mbsl) (Fig. F1).

Multichannel seismic reflection profiles crossing Site U1355 (Fig. F2) image three of the Wilkes Land margin regional unconformities (WL-U3, WL-U4, and WL-U5) (see the "Expedition 318 summary" chapter). Unconformity WL-U3 is observed between $\sim 782$ and 825 meters below seafloor (mbsf) $(5.95 \mathrm{~ms}$ two-way traveltime [TWT]) and was interpreted to separate preglacial strata below from glacial strata above. Thus, coring across unconformity WL-U3 was intended to document the first arrival of the ice sheet to the Wilkes Land Continental Margin. This "onset" of glaciation is presently inferred to have occurred during the earliest Oligocene (see the "Expedition 318 summary" chapter).

Site U1355 was also chosen to provide a distal record of OligocenePliocene(?) glacial-interglacial (i.e., colder versus warmer) and ice sheet variability. Regional unconformity WL-U5 is imaged in the seismic data at $\sim 709$ mbsf (5.6 s TWT) (Fig. F2). Unconformity WL-U5 represents a major shift in continental rise sedimentation with the onset of thick levee deposits above the unconformity. Coring across unconformity WL-U5 aimed to document the timing, nature, and cause of this shift in sedimentation.

Guided by the regional seismic interpretations, Site U1355 is where the uppermost sedimentary section is relatively thin, or has been eroded, so that unconformity WL-U3 could be reached at a shallower depth in contrast to other locations offshore the Wilkes Land margin.

Based on the seismic facies at Site U1355, the lithologies expected were fine-grained distal turbidites, contourites, and hemipelagites (Escutia et al., 1997, 2000, 2002; De Santis et al., 2003; Donda et al., 2003). This interpretation was supported by the sediments recovered from Deep Sea Drilling Project Leg 28 Site 269 (Hayes, Frakes, et al., 1975) located on the abyssal plain $\sim 280 \mathrm{~km}$ seaward from Site U1355.

Four cores from one hole were obtained at Site U1355. Cores 318U1355A-1R through $4 \mathrm{R}$ penetrated from 0 to $31.7 \mathrm{mbsf}$ and recov- 
ered $14.95 \mathrm{~m}(47 \%)$. The stratigraphic integrity of most of the core was highly compromised by drilling disturbance. The sediments are composed of angular igneous and metamorphic fragments. These fragments are unconsolidated, clast-supported, moderately to well-sorted sandy granule-pebble conglomerates grading upward into well-sorted, fine, crudely stratified sands. One $3 \mathrm{~cm}$ thick interbed of dark greenish gray diatom-bearing silty clay was preserved between two upward-fining units. The mechanism for the formation of the upward-fining beds is through gravity flow, most likely a high-density turbidity current.

Samples from Hole U1355A were analyzed for siliceous microfossils, foraminifers, and palynomorphs. Core catcher samples from Cores 318-U1355A-1R through $4 \mathrm{R}$ and additional samples from clay-rich clasts within the cores were analyzed for diatoms. The core material yielded an abundant Antarctic flora dominated by Fragilariopsis kerguelensis and Thalassiosira lentiginosa. The association of these typical Pleistocene-Holocene Antarctic diatoms along with common Actinocyclus ingens and Actinocyclus ingens var. ovalis indicates an age no older than late Pleistocene. Reworking from Miocene and Eocene material was recorded. A sample from the top of the hole yielded a rich and diverse modern (Holocene) Antarctic diatom assemblage. Radiolarians typical of late Pleistocene-Holocene Antarctic waters were also found in the core catchers and seafloor samples with an overall low abundance. The seafloor sample yielded a low-diversity planktonic foraminifer assemblage dominated by Neogloboquadrina pachyderma, indicating an age <9.2 Ma. Palynomorphs were recorded in the seafloor sample and Samples 318U1355A-1R-CC and 4R-CC. Notable finds included Holocene organic-walled dinoflagellate cysts (dinocysts), foraminifer linings, copepod eggs, reworked late Eocene dinocysts, and reworked Paleogene and/ or Cretaceous spores and pollen.

The physical property program for Hole U1355A cores included nondestructive measurements of gamma ray attenuation (GRA) densitometer bulk density, magnetic susceptibility, natural gamma ray (NGR) emission, and $P$-wave velocity on wholeround core sections. Whole-round and section-half core logging measurements are significantly affected by poor core quality, and the data are therefore compromised. Magnetic susceptibility values are relatively high, reflecting the lithologic composition of the individual clasts in the gravels and sands. The silty diatom-bearing clay clasts are characterized by pronounced lower magnetic susceptibility, bulk density, and sonic velocity values but higher NGR counts. $P$-wave velocities increase from $1800 \mathrm{~m} / \mathrm{s}$ at the seafloor to $>1920 \mathrm{~m} / \mathrm{s}$ at the base of Core 318U1355A-2R.

In summary, operations at Site 1355 revealed that the nature of the seafloor was not the expected finegrained sediments. After failing to core into the seafloor with the advanced piston corer (APC), the rotary core barrel (RCB) system was tried (see "Operations") and yielded $31.7 \mathrm{~m}$ of Pleistocene-Holocene unconsolidated coarse gravels and sands. The unconsolidated and coarse-grained nature of the sediment prevented any further advance. We decided to abandon Hole U1355A and move to Site U1356, where we could achieve the same scientific objectives.

\section{Operations}

\section{Wellington port call}

Expedition 318 began when the first line was secured to Aotea Quay, Centre Port, Berth 5, in Wellington, New Zealand, at $1420 \mathrm{~h}$ on 3 January 2010. All times in the operations section are given in local ship time unless otherwise noted. Initially this was Universal Time Coordinated (UTC) $+13 \mathrm{~h}$. During transit to the first site, the ship's clocks were set back $1 \mathrm{~h}$ at 1200 on 12 January to UTC $+12 \mathrm{~h}$ and then another $1 \mathrm{~h}$ at 2400 on 13 January to UTC $+11 \mathrm{~h}$, where it remained for the duration of the expedition.

As soon as routine customs and immigration formalities were concluded, off-loading of surface freight was initiated. The expedition United States Implementing Organization staff and Co-Chief Scientists boarded the ship on 4 January. In addition to routine replenishment of expendables and off-loading of the previous expedition's cores and returning freight, we loaded 740 MT of marine gasoil, repaired one of the thrusters and a propulsion motor, conducted laboratory/ ship tours for guests and visiting dignitaries, mounted the wind wall on the core receiving platform, and installed a new touch-screen rig instrumentation monitor in the drillers console.

Because this was a high-latitude expedition that operated in the challenging environment off the coast of Wilkes Land, Antarctica, two critical specialists were added to the shipboard team. A senior weather forecaster with previous IODP expedition experience joined the vessel to provide timely analysis of the complex weather environment of the Southern Ocean. A seasoned ice observer with extensive familiarity with both Arctic and Antarctic regions also joined the expedition. The combined skill set provided by these participants enhanced the safety of the vessel and optimized the ability of the crew to maximize on-site operational flexibility. 


\section{Transit to Site U1355}

The vessel departed on the $1847 \mathrm{nmi}$ journey to the first site when the last line was released from the dock at $1045 \mathrm{~h}$ on 9 January 2010. The vessel sailed at full speed, except for a short time during which the brushes on a propulsion motor (16 A) were replaced. By midnight on 9 January, the ship had sailed $116 \mathrm{nmi}$ at an average speed of $9.3 \mathrm{kt}$.

The ship transited south-southwest off the east coast of New Zealand's South Island. Preliminary analysis of ice coverage appeared to be promising for our first planned site (U1360) with temperatures in that region of $0.2^{\circ} \mathrm{C}$, winds from the east-southeast increasing to 35-40 kt, and cloudy conditions with occasional snow or sleet.

The vessel passed within $30 \mathrm{nmi}$ of Auckland Island on the morning of 12 January. Once the vessel moved south of the protection of Auckland Island, it was exposed to the open expanse of the Southern Ocean and the powerful low-pressure systems that populate this region. The vessel negotiated through intense winds and sea conditions from 12 January until the morning of 15 January. Frequent course changes and reductions in speed were made to avoid the most intense parts of a large and severe lowpressure system that was crossing the projected ship track. Even though the vessel remained on the outer edge of the system, the combined sea and swell reached $40 \mathrm{ft}$ and the winds were clocked at as high as $60 \mathrm{kt}$. Vessel motion ranged from moderate to heavy and on one occasion the ship experienced a $13^{\circ}$ roll. The ship's clocks were set back $1 \mathrm{~h}$ at 1200 on 12 January to UTC $+12 \mathrm{~h}$ and then another $1 \mathrm{~h}$ at 2400 on 13 January to UTC $+11 \mathrm{~h}$.

The vessel began to ride more smoothly in improving sea conditions by the afternoon of 15 January and was proceeding at nearly $10 \mathrm{kt}$ to Site U1360. During the evening, the first penguins were observed, hinting that we might be approaching ice-strewn waters. At $0345 \mathrm{~h}$ on 16 January, the first iceberg was spotted on radar at $9 \mathrm{nmi}$ and then visually observed at $5 \mathrm{nmi}$ through the fog and mist as it passed on the port side. It was pinnacled and rigged and estimated to be $\sim 300 \mathrm{ft}$ long and $50 \mathrm{ft}$ high. There were also a few growlers in the vicinity. During the day, the vessel speed was reduced when fog and mist reduced the visibility to $<1 / 8 \mathrm{nmi}$. At $0440 \mathrm{~h}$ on the morning of 17 January, ship's radar picked up a large iceberg at $17 \mathrm{nmi}$ with a calculated closest point of approach of $7 \mathrm{nmi}$ to starboard.

By midnight on 16 January, the vessel had traveled $1505 \mathrm{nmi}$ at an average speed of $8.3 \mathrm{kt}$. The estimated time of arrival on site was mid-morning on 18 January. Satellite analysis of ice coverage in the re- gion indicated the drill site area was mostly free of large icebergs and floes. The winds at our first site were forecasted to pick up and peak at $\sim 40 \mathrm{kt}$ the evening of 18 January and then decrease. Temperatures were expected to be $\sim 0^{\circ} \mathrm{C}$. The new long-range outlook through 22 January indicated good weather conditions on site.

Throughout the week, the drilling crew continued preparations for drilling operations in the severe Antarctic weather conditions. A wind wall was constructed around the drill floor, exposed piping (heating, air, drain, and water) was insulated, electrical lines were run for heaters in the mud pump room and behind the drawworks, and external space heaters were tested.

As we approached Site U1360 at the reduced speed of $8 \mathrm{kt}$, the captain received an updated satellite image from the National Ice Center that indicated a large tongue of ice in the direct path to Site U1360. This was obscured in previous imagery by cloud cover. This necessitated adding a dogleg in the track to Site U1360 so that we could steer around the leading edge of the tongue.

As the vessel altered course and speed in heavy mist and fog, large icebergs began to appear on the radar and a few growlers were spotted visually. When the fog suddenly cleared, icebergs of various shapes and sizes were observed around the vessel. The vessel proceeded at slow speed attempting to approach Site U1360 amid the ice when the weather deteriorated during the afternoon of 18 January. With the winds gusting to $35 \mathrm{kt}$ and accompanied by snow and reduced visibility, the effort to reach Site U1360 was suspended $19 \mathrm{nmi}$ short of the objective until ice conditions were more favorable. The captain altered course to Site U1355 located $~ 167 \mathrm{nmi}$ to the northnorthwest. The most recent satellite pictures indicated that Site U1355 appeared to be free of floating ice.

\section{Site U1355}

The vessel exited the hostile ice conditions and proceeded at an average speed of $6.4 \mathrm{kt}$ to Site U1355, arriving on site at $1045 \mathrm{~h}$ on 19 January 2010. The circuitous voyage from Wellington to the first site covered $2021 \mathrm{nmi}$ at an average speed of $8.5 \mathrm{kt}$. During the voyage from the area of Site U1360 to Site U1355, no icebergs were spotted on the radar or visually.

An APC/extended core barrel bottom-hole assembly (BHA) was made up with an 117/16 inch bit and lowered to the seafloor. The initial mudline attempt was made at $0705 \mathrm{~h}$ on 20 January with the bit at 3735 meters below rig floor (mbrf; $5.7 \mathrm{~m}$ shallower than the corrected depth of 3740.7 mbrf inferred from the precision depth recorder). When the core 
barrel was recovered, we found that the bottom of it had broken off at the connection joining the two $4.5 \mathrm{~m}$ nonmagnetic sections. To test the nature of the seafloor, the driller gently tagged seafloor with the bit at $\sim 3740$ mbrf. The bit was slowly rotated and a mild increase in torque was observed, indicating that the seafloor was firm but apparently not unusually hard.

Another mudline core was attempted using the more durable standard steel core barrels with the bit positioned at 3735 mbrf. The pressure bleed-off indicated a full stroke but the core winch operator was unable to recover the APC core barrel with the coring line. For nearly $1.5 \mathrm{~h}$, the core winch operator and driller tried various techniques to recover the corer with the coring line without success. The only recourse was to recover the drill string. The bit was back on the rig floor at $2225 \mathrm{~h}$ on 20 January. This second APC core barrel was also broken off. Once the remains of the core barrel were cleared from the bit throat, it was decided to attempt a spud with the RCB coring system.

An RCB BHA with a new C-4 97\% inch bit and mechanical bit release were made up and deployed. The seafloor depth was again confirmed at $3740.0 \mathrm{mbrf}$ (3729.0 mbsl) by the driller gently tagging the bit on the seafloor. Coring in Hole U1355A was finally started at $0905 \mathrm{~h}$ on 21 January. The first core advanced $3.5 \mathrm{~m}$ but recovered $5.3 \mathrm{~m}$ of core. This could have occurred because of uncertainty in the precise seafloor depth and/or by the drill bit repeatedly tagging the seafloor as a result of ship heave. RCB Cores $318-\mathrm{U} 1355 \mathrm{~A}-1 \mathrm{R}$ through $4 \mathrm{R}$ penetrated from 0 to $31.7 \mathrm{mbsf}$ and recovered $14.95 \mathrm{~m}$ (47\%) (Table T1). The cores recovered unconsolidated coarse sands and gravel, so the recovery was quite remarkable. However, coring had to be terminated because of unstable hole conditions caused by the coarse and unconsolidated sediments.

We decided to abandon this site and find an area less hostile to coring. We considered making another attempt to return to the shelf sites, but based on remote sensing data and information from a research vessel in that region it was felt that ice conditions in the area had not significantly improved. Instead, we decided to move to Site U1356, located $82 \mathrm{nmi}$ westnorthwest of Site U1355. After a total time of 2.8 days on site, we departed Site U1355 at $0600 \mathrm{~h}$ on 22 January.

\section{Lithostratigraphy}

One hole was drilled at Site U1355 to a total depth of 31.7 mbsf using the RCB system. Core 318-U1355A$1 \mathrm{R}$ recovered $5.30 \mathrm{~m}$ of sediment over a drilling advancement of $3.50 \mathrm{~m}$. The core contained two fining-upward sand and gravel beds separated by a silty clay bed. Core $1 \mathrm{R}$ appears relatively undisturbed with preservation of sedimentary structures in fine sands, although portions of the gravel beds in this core were washed by the drilling process. The stratigraphic integrity of Cores $2 \mathrm{R}$ through $4 \mathrm{R}$ was highly compromised by drilling disturbance. Core $3 \mathrm{R}$ recovered $5 \mathrm{~cm}$ of sediment, all processed for micropaleontology. Drilling disturbance in Cores $2 \mathrm{R}$ and $4 \mathrm{R}$ is characterized by sands and coarse fall-in material.

\section{Unit descriptions}

\section{Unit I}

Interval: 318-U1355A-1R-1, $0 \mathrm{~cm}$, through 4R-CC, $22 \mathrm{~cm}$

Depth: 0.0-24.88 mbsf

Age: Pleistocene to Holocene

Lithostratigraphic Unit I is composed of clast-supported moderately to well-sorted sandy granule-pebble gravels grading upward into well-sorted, fine, crudely stratified sands. A single $3 \mathrm{~cm}$ thick drilling-disturbed interbed of dark greenish gray diatom-bearing silty clay was preserved between two upward-fining units in Core 318-U1355A-1R (Fig. F3). In Cores 2R and $4 \mathrm{R}$, the upper $40-100 \mathrm{~cm}$ of each core is characterized by disturbed coarse sands grading upward into fine sands. Occasional pebble- and cobble-sized clasts are present.

The gravel beds in Hole U1355A are polymict throughout. Clast lithologies are dominated by granitic gneiss, diorite, dark metamorphic rocks, and metasediments. Olive-gray intraformational clasts composed of silt-rich diatom ooze with a late Pleistocene-Holocene diatom assemblage, diatom clayey silt, and silty clay are also present. Rock clasts are angular to subangular in shape, and some pebble-sized clasts are faceted.

The silt and sand material recovered from Hole U1355A, as estimated from smear slides, is composed of mixtures of generally $<50 \%$ quartz, with accessory feldspars, heavy minerals, and lithics. The silty intraclasts consist of $10 \%$ to $>50 \%$ diatoms, with subordinate radiolarians and sponge spicules. The dark greenish gray diatom-bearing silty clay bed in interval 318-U1355A-1R-3, 91-94 cm, at the top of one of the fining-upward beds, has $\sim 10 \%$ diatom fragments and other highly fragmented biogenic siliceous debris.

\section{Discussion}

Based on the preservation of three relatively intact sections in Core 318-U1355A-1R, we infer that the likely mechanism for the formation of the fining-upward beds is gravity flow. The texturally and compositionally immature character of the sediments and the 
angular clast shapes indicate that traction transport was minimal. The fining-upward texture of the beds indicates fluidal flow, with sufficient water sheared into the flow to allow particle size segregation by gravity settling. We interpret this as a high-density turbidity current (Lowe, 1982). The intraformational clasts of late Pleistocene-Holocene diatom ooze and silty clay could be interpreted as rip-up clasts, but it cannot be ruled out that these result from fall-in derived from material from the modern seafloor. The age of the flow is late Pleistocene or younger based on the diatom assemblages within the diatom-bearing silty clay (interval 318-U1355A-1R-3, 91-94 cm) in the portion of Core $1 \mathrm{R}$ that was only slightly disturbed.

The terrigenous material within the sediment has a clear glacigenic signature. Therefore, the source material for the flow must have been a glacigenic sediment. Glacigenic sediments were likely transported as debris flows with a transition to high-density turbidity currents through shearing at the debris/water interface and entrainment of seawater. Gravity flow could have commenced at any point along the outer continental shelf, continental slope, or continental rise. Both local winnowing of the matrix of older Neogene debris flows or winnowing of contemporaneous debris flows derived from higher up the continental slope is possible (Escutia et al., 2007).

\section{Biostratigraphy}

Unconsolidated gravels and coarse sands were recovered from Hole U1355A with minor amounts of diatom-bearing silty clay and clasts of diatom-bearing silty clays to silt-rich diatom ooze. Selected clay-rich clasts from Cores 318-U1355A-1R through 4R, as well as the top $(0-1 \mathrm{~cm})$ of Section $1 \mathrm{R}-1$, were analyzed for microfossil content. The results are summarized in Table T2.

\section{Siliceous microfossils}

\section{Diatoms, silicoflagellates, and sponge spicules}

Diatoms, silicoflagellates, and sponge spicules occur throughout the clay-rich clasts and core-top material analyzed in Hole U1355A. Diatoms are common to abundant in Core 1R (including the core top) and present at trace to common abundances in Cores $2 \mathrm{R}$ through $4 \mathrm{R}$.

The assemblage in Sample 318-U1355A-1R-1, 0-1 cm, is well preserved and comprises typical Antarctic diatom species including notably Actinocyclus curvatulus (and Actinocyclus spp.), Azpeitia tabularis, Dactyliosolen antarcticus, Eucampia antarctica, Fragilariopsis curta, F. kerguelensis, Fragilariopsis rhombica, Fragilariopsis ritscheri, Fragilariopsis separanda, Shionodiscus gracilis, Thalassiosira antarctica, T. lentiginosa, Thalassiosira trifulta, and Thalassiothrix antarctica. Trace occurrences of $A$. ingens and Denticulopsis spp. indicate reworked Miocene material. Sample 318-U1355A-1R$1,0-1 \mathrm{~cm}$, is assigned to the Holocene based on these assemblage characteristics and the absence of common late Pleistocene and older index species.

The diatom assemblages in Samples 318-U1355A-1R$1,70 \mathrm{~cm}$, through 4R-CC (Table T2) are moderately to well preserved and dominated by F. kerguelensis and $T$. lentiginosa with trace to few occurrences of $A$. ingens (reworked or more likely in situ toward the top of its range at $0.5-0.57 \mathrm{Ma}$ according to the average range model of Cody et al., 2008). Other species occurring at trace to common abundance include $A c$ tinocyclus actinochilus (and Actinocyclus spp.), Asteromphalus parvulus, A. tabularis, Chaetoceros resting spores, D. antarcticus, E. antarctica, F. curta, Fragilariopsis cylindrus, Fragilariopsis obliquecostata, F. rhombica, F. ritscheri, F. separanda, Fragilariopsis sublinearis, Fragilariopsis vanheurckii, Paralia sulcata, Proboscia spp., Rhizosolenia spp., Rouxia spp., S. gracilis, Stellarima microtrias, Stephanopyxis spp., T. antarctica, Thalassiosira oliverana, Thalassiosira tumida, T. antarctica, Trichotoxon reinboldii, the silicoflagellate Distephanus speculum, and sponge spicules. Trace to few occurrences of $A$. ingens var. ovalis, Denticulopsis spp., Thalassiosira elliptipora, Thalassiosira inura, Thalassiosira torokina, and Thalassiosira vulnifica indicate reworked Miocene and Pliocene material.

Cores 318-U1355A-2R through 4R contain a similar floral assemblage to that recovered in Core $1 \mathrm{R}$ but with more extensive reworking of Pliocene (T. inura), Miocene (Denticulopsis spp. and A. ingens var. ovalis), and probably older material (e.g., stephanopyxids and the ebridian Pseudammodochium lingii).

A middle Pleistocene-Holocene age is assigned to Samples 318-U1355A-1R-1, $70 \mathrm{~cm}$, through 4R-CC based on the consistent and abundant presence of $A$. ingens and the absence of in situ index species for the early Pleistocene or older.

\section{Radiolarians}

A typical Antarctic Holocene radiolarian assemblage characterized by Antarctissa denticulata, Antarctissa strelkovi, Spongotrochus glacialis, and Cycladophora davisiana is present in Sample 318-U1355A-1R-1, 0$1 \mathrm{~cm}$. Sample 2R-1, 149-150 cm, is barren of radiolarians, whereas Samples 3R-CC and 4R-CC contain only very rare specimens. The assemblage is similar to that recovered in Sample 1R-1, 0-1 cm, but includes some reworked specimens such as Prunopyle titian and Cycladophora spongothorax. These radiolarian assemblages suggest an age younger than latest Miocene. 


\section{Palynology}

Four samples from Hole U1355A were processed for palynology: Samples 318-U1355A-1R-1, 0-1 cm; 1R1, 68.5-71.5 cm; 1R-1, 71.5-73.5 cm; and 4R-1, 34$35 \mathrm{~cm}$. Palynomorphs are found in trace amounts and preservation is moderate to poor.

The palynological associations contain both marine (primarily dinoflagellate cysts, or dinocysts) and terrestrial (sporomorphs and phytoclasts) components. Other marine palynomorphs include acritarchs, copepod eggs, and foraminifer test linings.

Most dinocysts are reworked from the Eocene, as indicated by the occurrence of, for example, Enneadocysta dictyostila, Phthanoperidinium comatum, Phthanoperidinium stockmansii, Spinidinium macmurdoense, Vozzhennikovia apertura, Vozzhennikovia netrona, and Vozzhennikovia stickleyae. Findings of Deflandrea sp. A of Brinkhuis et al. (2003) and Turbiosphaera filosa further constrain this reworking to the latest Eocene. All of the above-mentioned species are known to reach high abundances in uppermost Eocene strata of the Tasman region (e.g., Sluijs et al., 2003). In addition to the markers for the late Eocene, species characteristic of the Holocene were also identified, namely Brigantedinium spp. and Impagidinium pallidum. The latter occurs in relatively high abundances in all samples, and the general transparency of the specimens strongly suggests that they are in situ, thus reflecting a Holocene age. No dinocysts with stratigraphic ranges limited to the Oligocene, Miocene, or Pliocene were recorded. Hence, the dinocysts exhibit a bimodal age distribution, with a major component of likely late Eocene origin reworked into Holocene material.

Terrigenous input is indicated by sporomorphs and phytoclasts; representatives of both groups occur in trace amounts in all samples. The sporomorphs comprise both pollen (bisaccates, Classopollis, and Nothofagus) and spores (Baculatisporites, Deltoidospora, and Lycopodiumsporites). Findings particularly of Classopollis and Nothofagus suggest reworking from older (Paleogene and Mesozoic) strata, which is only partially consistent with the dinocyst-based age information; they indicate the presence of at least one additional (i.e., pre-Eocene) host-rock source.

\section{Foraminifers}

Foraminifers were recovered only in the uppermost section of Hole U1355A (Sample 318-U1355A-1R-1, 0-1 cm). All core catcher samples are barren of foraminifers. In Sample 318-U1355A-1R-1, 0-1 cm, a planktonic foraminifer assemblage characteristic of the high-latitude Southern Ocean was identified. This low-diversity assemblage consists mainly of $N$. pachyderma (84\%), Globigerina bulloides (10\%), and Globigerina uvula (2\%). Preservation is good, with no evidence of reworking. Benthic foraminifers include Oridorsalis umbonatus, Globocassidulina subglobosa, Astoculus credidus, and Nonion spp.

\section{Summary}

Sample 318-U1355A-1R-1, 0-1 cm, and clay-rich clasts from Cores 318-U1355A-1R through 4R yield diatoms, silicoflagellates, radiolarians, sponge spicules, dinoflagellate cysts and sporomorphs, and planktonic foraminifers. Diatoms are the most abundant group and the most useful for age determination; they suggest a middle Pleistocene-Holocene age for Hole U1355A. This age assessment is supported by the other investigated microfossil groups. In addition, diatoms and radiolarians indicate Pliocene and Miocene reworking, whereas palynology indicates moderate to strong reworking of late and middle Eocene material. Pollen and spores also indicate Mesozoic reworking.

\section{Physical properties}

The shipboard physical properties program at Site U1355 included nondestructive measurements of GRA bulk density, magnetic susceptibility (loop sensor), NGR, and $P$-wave velocity on whole-round core sections. Point sensor magnetic susceptibility, spectrophotometry, and colorimetry were determined on section halves from Hole U1355A.

All measurements were made on all RCB cores in Hole U1355A to 24.9 mbsf (Section 318-U1355A-4R$\mathrm{CC})$. Because of drilling disturbance associated with RCB coring and the slightly smaller diameter of the core relative to that of the core liner, whole-round magnetic susceptibility, GRA density, and $P$-wave measurements were degraded in quality. In general, the various measurements on sections from Hole U1355A correlate well. No discrete moisture and density analyses were undertaken because of the degree of drilling disturbance of these unconsolidated sediments.

\section{Gamma ray attenuation bulk density}

GRA density was measured at $2.5 \mathrm{~cm}$ intervals (5 s measurement time). Variations in GRA density may reflect varying concentrations of sands, gravel, and/or clays related to composition of these glacial sediments (Fig. F4).

\section{Magnetic susceptibility}

Whole-core magnetic susceptibility was measured at $2.5 \mathrm{~cm}$ intervals (2 s measurement time). The raw 
data values range from 111 to 2332.8 instrument units (Fig. F4). These values are quite high but represent the lithologic composition of the individual clasts in the gravel and sand of the sediment.

Magnetic susceptibility was also measured at $2.5 \mathrm{~cm}$ intervals ( $1 \mathrm{~s}$ measuring time) on the Section Half Multisensor Logger using a MS2E point sensor (MSP) (Fig. F4). Magnetic susceptibility data measured with the MSP show poor correlation with data obtained from the Whole-Round Multisensor Logger (WRMSL) measurements made on whole-round core sections except for the upper $3 \mathrm{~m}$.

\section{Natural gamma radiation}

NGR was measured on all core sections at $10 \mathrm{~cm}$ intervals. Values measured ranged from 24 to $55 \mathrm{cps}$, with lower values associated with gravel/sand and higher values associated with muddy lithologies.

\section{P-wave velocities}

$P$-wave velocity measurements were made at $5 \mathrm{~cm}$ intervals on the WRMSL. Within the upper $\sim 10 \mathrm{~m}$, velocity values range from 1820 to $1920 \mathrm{~m} / \mathrm{s}$. In the uppermost $\sim 3.0 \mathrm{~m}, P$-wave velocity decreases from 1800 to $1640 \mathrm{~m} / \mathrm{s}$ where mud clasts occur. Unfortunately, the data yielded very poor results caused by signal attenuation resulting from high porosity of the loose gravel and sand.

\section{References}

Brinkhuis, H., Sengers, S., Sluijs, A., Warnaar, J., and Williams, G.L., 2003. Latest Cretaceous-earliest Oligocene and Quaternary dinoflagellate cysts, ODP Site 1172, East Tasman Plateau. In Exon, N.F., Kennett, J.P., and Malone, M.J., Proc. ODP, Sci. Res., 189: College Station, TX (Ocean Drilling Program), 1-36. doi:10.2973/ odp.proc.sr.189.106.2003

Cody, R.D., Levy, R.H., Harwood, D.M., and Sadler, P.M., 2008. Thinking outside the zone: high-resolution quantitative diatom biochronology for the Antarctic Neogene. Palaeogeogr., Palaeoclimatol., Palaeoecol., 260(12):92-121. doi:10.1016/j.palaeo.2007.08.020

De Santis, L., Brancolini, G., and Donda, F., 2003. Seismostratigraphic analysis of the Wilkes Land continental margin (East Antarctica): influence of glacially driven processes on the Cenozoic deposition. Deep-Sea Res., Part II, 50(8-9):1563-1594. doi:10.1016/S09670645(03)00079-1
Donda, F., Brancolini, G., De Santis, L., and Trincardi, F., 2003. Seismic facies and sedimentary processes on the continental rise off Wilkes Land (East Antarctica): evidence of bottom current activity. Deep-Sea Res., Part II, 50(8-9):1509-1527. doi:10.1016/S0967-

0645(03)00075-4

Escutia, C., Donda, F., Lobo, F. J., and Tanahashi, M., 2007. Extensive debris flow deposits on the eastern Wilkes Land margin: a key to changing glacial regimes. In Cooper, A., Raymond, C., and the 10th ISAES Editorial Team (Eds.), Antarctica: A Keystone in a Changing WorldOnline Proceedings for the 10th International Symposium on Antarctic Earth Sciences. Open-File Rep.-U. S. Geol. Surv., 2007-1047:026. doi:10.3133/of20071047.srp026

Escutia, C., Eittreim, S.L., and Cooper, A.K., 1997. Cenozoic sedimentation on the Wilkes Land continental rise, Antarctica. In Ricci, C.A. (Ed.), The Antarctic Region: Geological Evolution and Processes. Proc. Int. Symp. Antarct. Earth Sci., 7:791-795.

Escutia, C., Eittreim, S.L., Cooper, A.K., and Nelson, C.H., 2000. Morphology and acoustic character of the Antarctic Wilkes Land turbidite systems: ice-sheet-sourced versus river-sourced fans. J. Sediment. Res., 70(1):84-93. doi:10.1306/2DC40900-0E47-11D78643000102C1865D

Escutia, C., Nelson, C.H., Acton, G.D., Eittreim, S.L., Cooper, A.K., Warnke, D.A., and Jaramillo, J.M., 2002. Current controlled deposition on the Wilkes Land continental rise, Antarctica. In Stow, D.A.V., Pudsey, C.J., Howe, J.A., Faugeres, J.-C., and Viana, A.R. (Eds.), Deep-Water Contourite Systems: Modern Drifts and Ancient Series, Seismic and Sedimentary Characteristics. Mem.Geol. Soc. London, 22(1):373-384. doi:10.1144/ GSL.MEM.2002.022.01.26

Hayes, D.E., Frakes, L.A., et al., 1975. Init. Repts. DSDP, 28: Washington, DC (U.S. Govt. Printing Office). doi:10.2973/dsdp.proc.28.1975

Lowe, D.R., 1982. Sediment gravity flows, II. Depositional models with special reference to the deposits of highdensity turbidity currents. J. Sediment. Petrol., 52(1):279297. http://jsedres.sepmonline.org/cgi/content/ abstract/52/1/279

Sluijs, A., Brinkhuis, H., Stickley, C.E., Warnaar, J., Williams, G.L., and Fuller, M., 2003. Dinoflagellate cysts from the Eocene-Oligocene transition in the Southern Ocean: results from ODP Leg 189. In Exon, N.F., Kennett, J.P., and Malone, M.J. (Eds.), Proc. ODP, Sci. Results, 189: College Station, TX (Ocean Drilling Program), 142. doi:10.2973/odp.proc.sr.189.104.2003

Publication: 2 July 2011 MS 318-103 
Figure F1. A. Bathymetric map of eastern Wilkes Land margin showing the location of Site U1355 and other Expedition 318 drill sites. Contour interval $=250 \mathrm{~m}$. Box $=$ approximate area of B. B. Navigation map of seismic reflection profiles across and in the vicinity of Site U1355. Bold lines $=$ multichannel seismic reflection profiles shown in Figure F2.

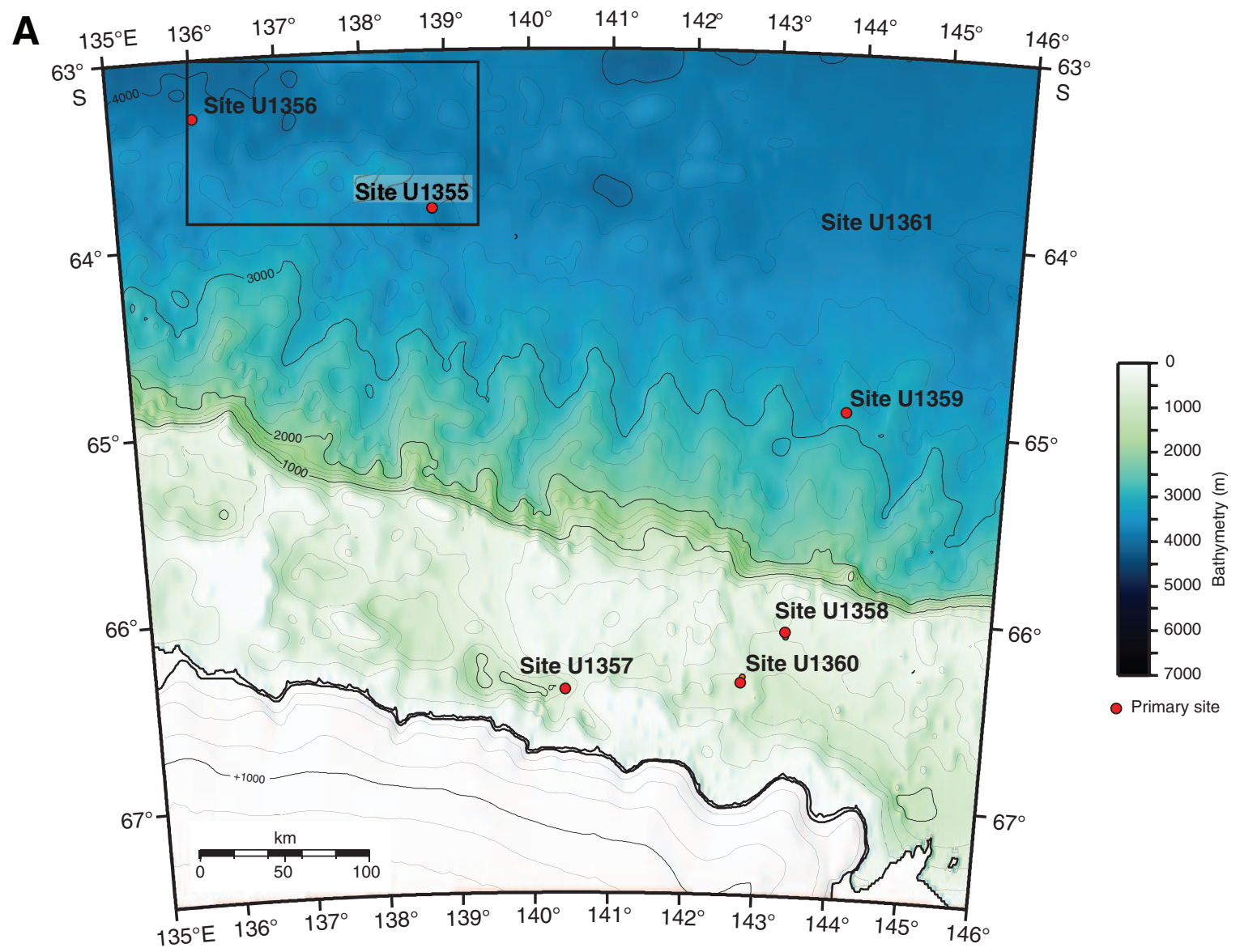

B

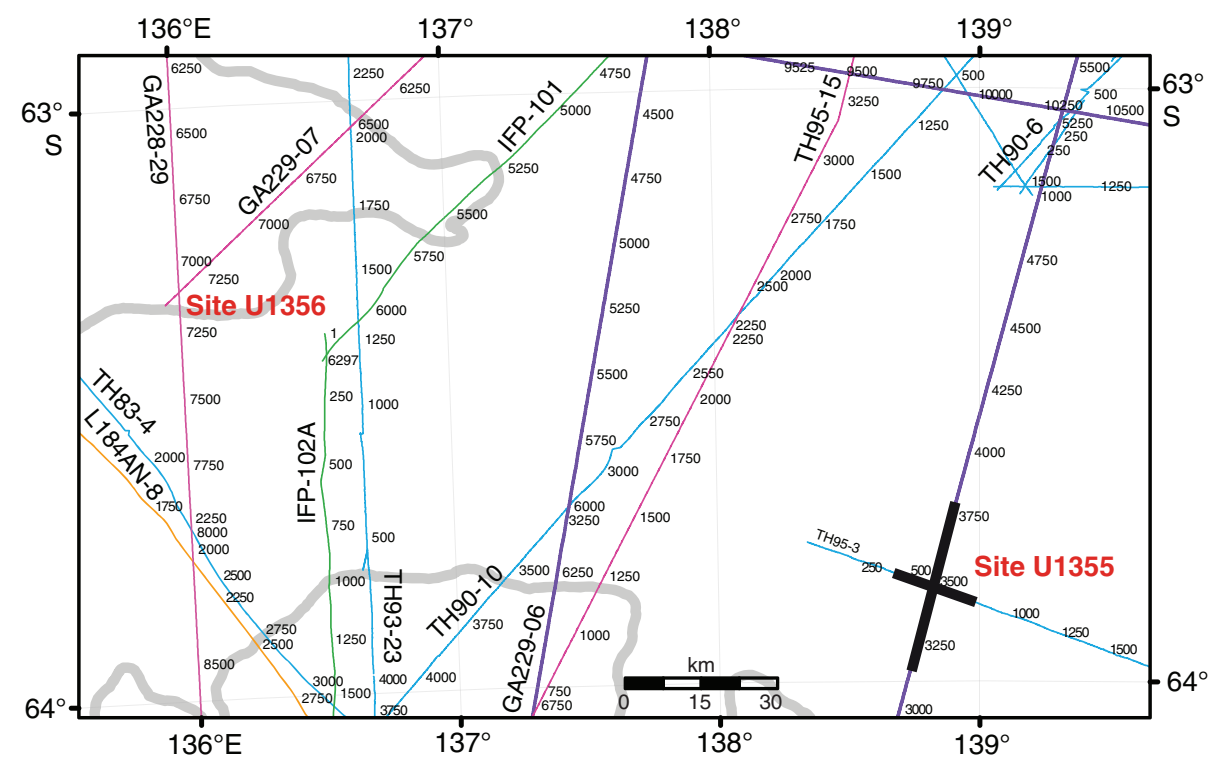


Figure F2. Seismic reflection profiles across Site U1355 showing regional unconformities WL-U3, WL-U4, and WL-U5. Solid red rectangle indicates approximate, very shallow penetration achieved at Site U1355 as compared to the target penetration depth (open rectangle). Location of seismic profiles is shown in Figure F1.
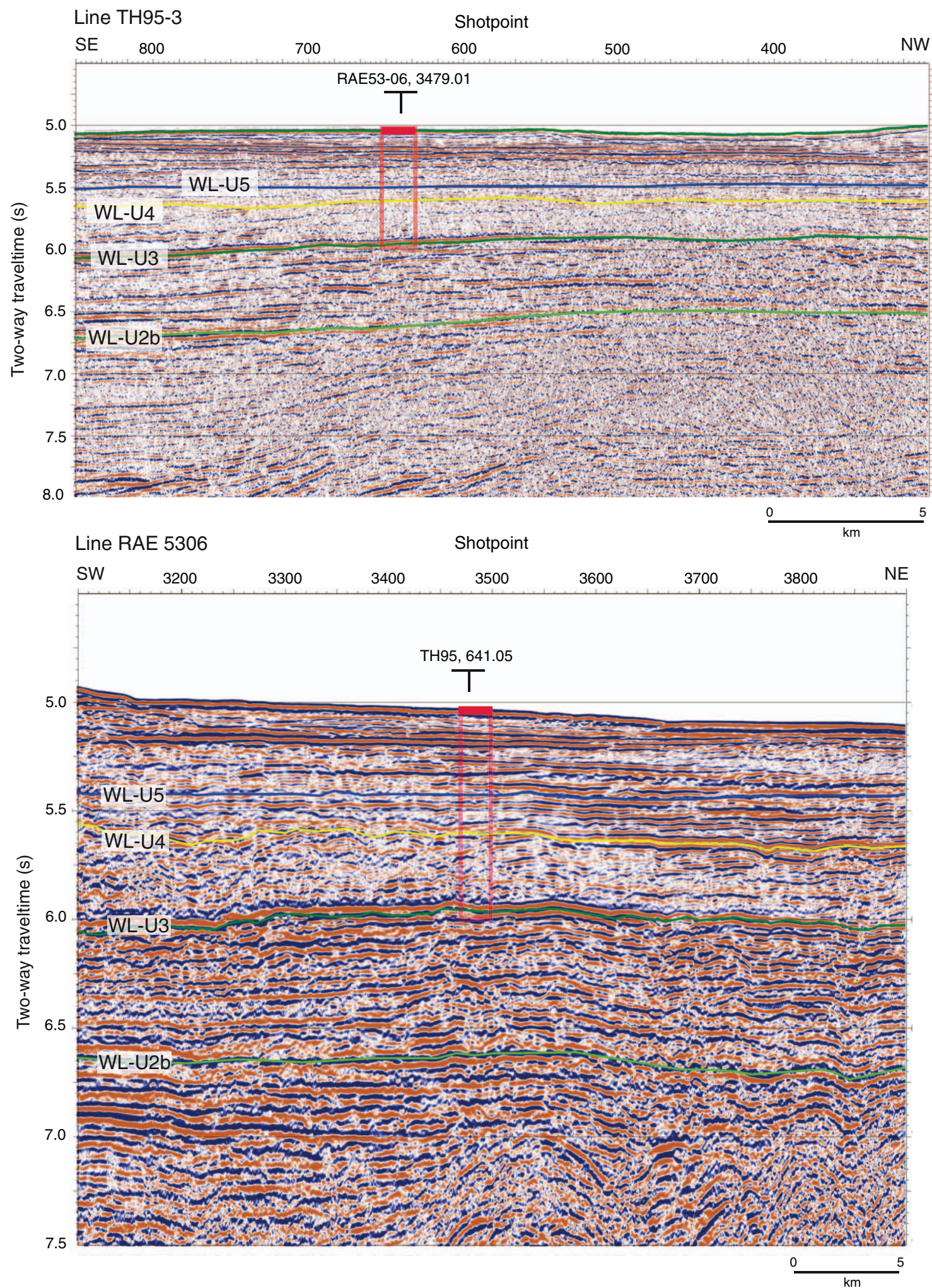
Figure F3. Upward-fining gravel and sand beds. In interval 318-U1355A-1R-3, 90-94 cm, the sand and gravel bed is capped by a disturbed diatom-bearing silty clay bed.

Figure F4. Raw data for magnetic susceptibility (loop and point sensors), gamma ray attenuation (GRA) bulk density, natural gamma radiation (NGR), and $P$-wave velocity, Hole U1355B. PWL $=P$-wave logger.

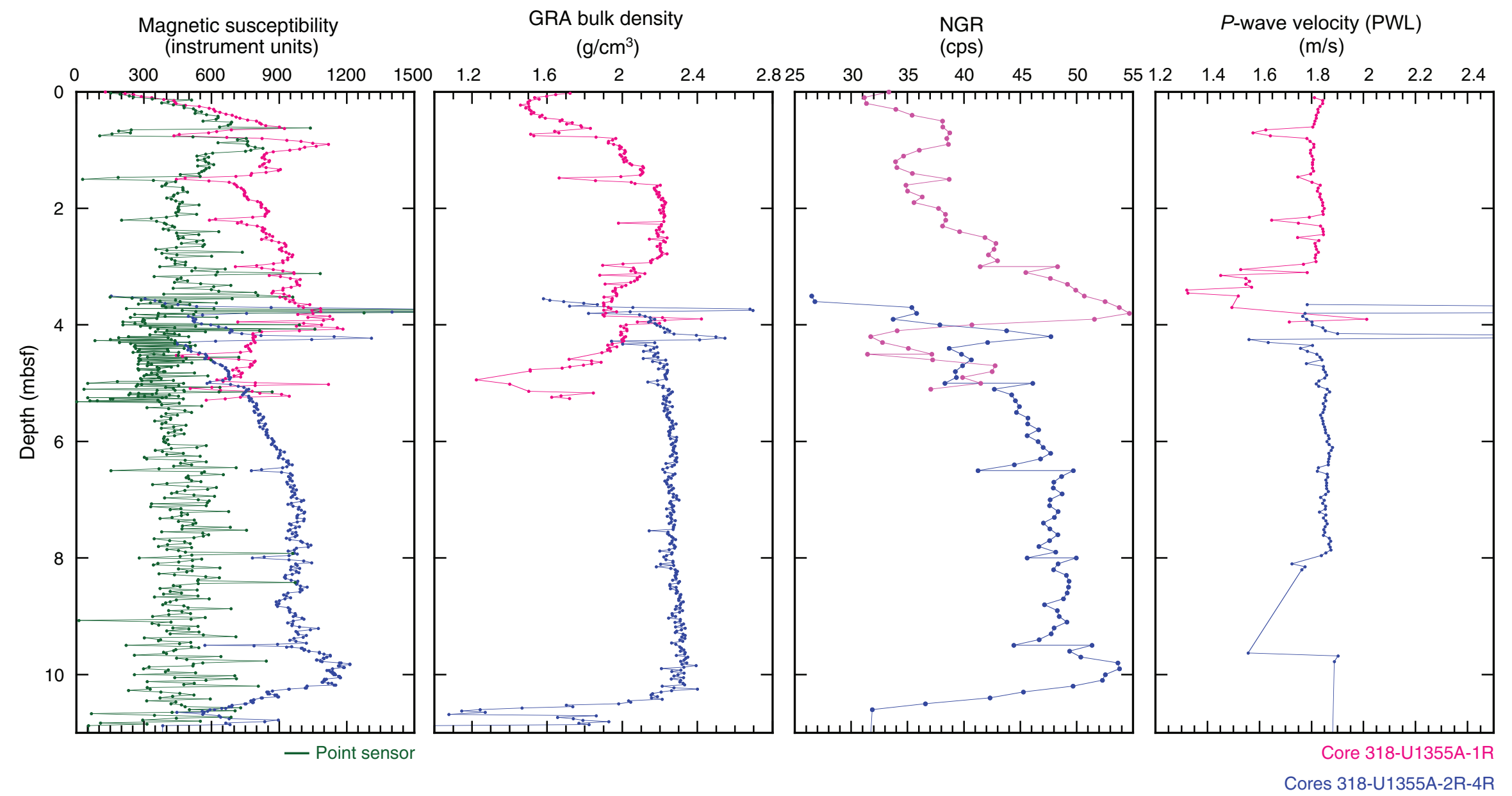


Table T1. Coring summary, Site U1355. (See table notes.)

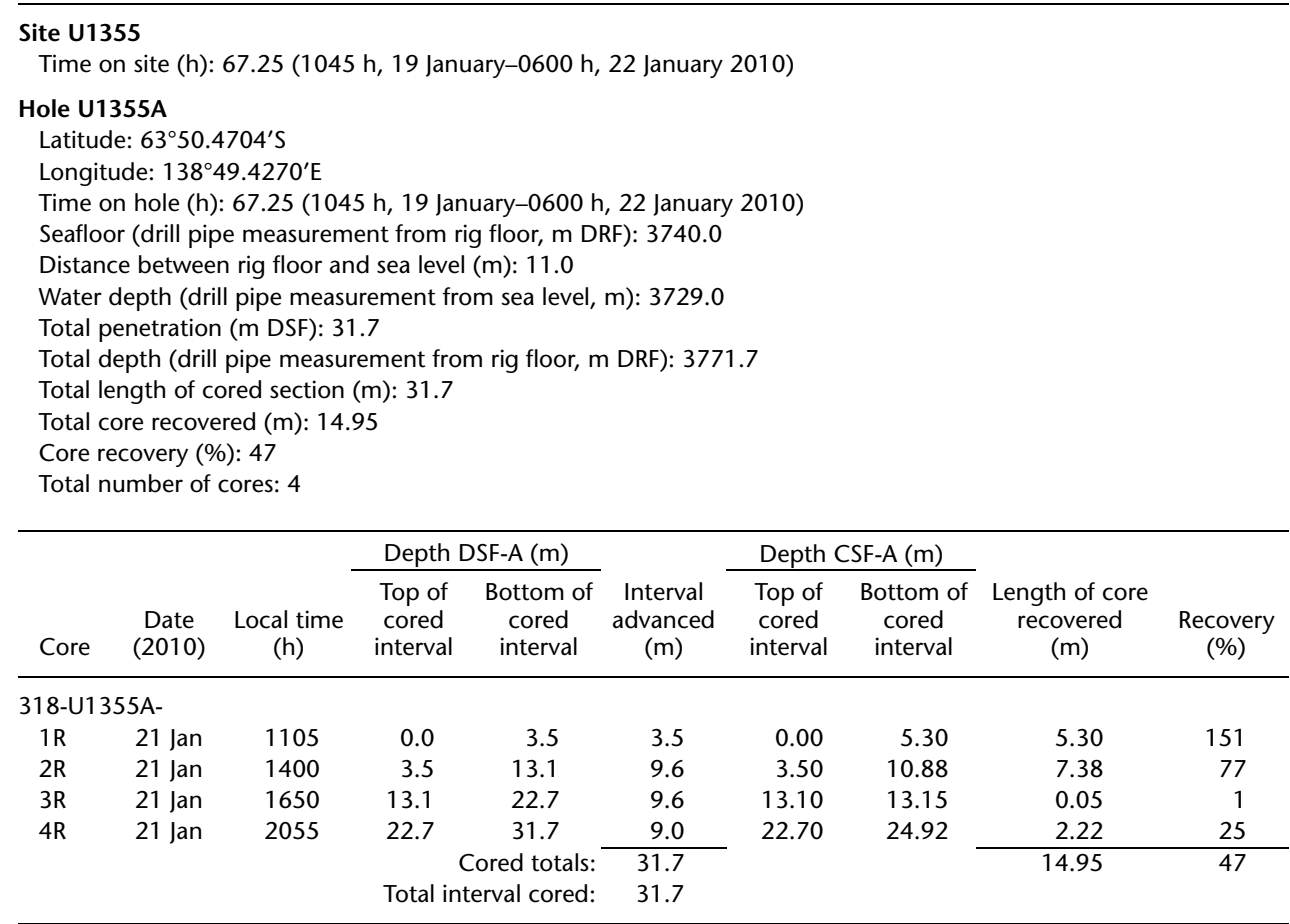

Notes: DRF = drilling depth below rig floor. DSF-A = drilling depth below seafloor, determined by tagging seafloor, CSF-A = core depth below seafloor, overlap if long. Local time $=$ UTC $+11 \mathrm{~h}$. 
Table T2. Analyzed interval summary and results, Hole U1355A. (See table note.)

\begin{tabular}{|c|c|c|c|c|}
\hline $\begin{array}{l}\text { Core, section, } \\
\text { interval }(\mathrm{cm})\end{array}$ & Diatoms & Radiolarians & Palynomorphs & Foraminifers \\
\hline \multicolumn{5}{|l|}{ 318-U1355A- } \\
\hline $1 \mathrm{R}-1,0-1$ & Diverse and abundant Holocene Antarctic flora & Typical Holocene Antarctic fauna & Holocene dinocysts and other palynomorphs & $\begin{array}{l}\text { Low-diversity, high-latitude Southern } \\
\text { Ocean assemblage }\end{array}$ \\
\hline $1 \mathrm{R}-1,68.5-71.5$ & NP & NP & Reworked Paleogene palynomorphs & NP \\
\hline 1R-1, 70-71 & $<$ middle Pleistocene flora, with Miocene-Pliocene reworking & NP & NP & NP \\
\hline $1 \mathrm{R}-1,71.5-73.5$ & NP & NP & Reworked Paleogene palynomorphs & NP \\
\hline $1 \mathrm{R}-3,91-93$ & $<$ middle Pleistocene flora, with Miocene-Pliocene reworking & NP & NP & NP \\
\hline 2R-1, 77-79 & $<$ middle Pleistocene flora, with Miocene-Pliocene reworking & NP & NP & NP \\
\hline $2 \mathrm{R}-1,82-84$ & $<$ middle Pleistocene flora, with Miocene-Pliocene reworking & NP & NP & NP \\
\hline $2 \mathrm{R}-1,149-150$ & $<$ middle Pleistocene flora, with Miocene-Pliocene reworking & Barren & NP & NP \\
\hline $3 \mathrm{R}-\mathrm{CC}, 0-5$ & $<$ middle Pleistocene flora, with Miocene-Pliocene reworking & Rare specimens, some reworking & NP & Barren \\
\hline $4 \mathrm{R}-1,34-35$ & NP & NP & Reworked Paleogene palynomorphs & NP \\
\hline 4R-CC, 19-21 & $<$ middle Pleistocene flora, with Miocene-Pliocene reworking & Rare specimens, some reworking & NP & Barren \\
\hline
\end{tabular}

Note: $\mathrm{NP}=$ not processed 